Article

\title{
Cultural Landscape Assessment: The Rural Architectural Heritage (13th-17th Centuries) in Mediterranean Valleys of Marina Alta, Spain
}

\author{
Alba Soler-Estrela \\ Department of Industrial Systems Engineering and Design, Universitat Jaume I, Avda. Sos Baynat s/n, \\ 12071 Castellón de la Plana, Spain; estrela@uji.es
}

Received: 28 June 2018; Accepted: 9 October 2018; Published: 11 October 2018

\begin{abstract}
Europe's cultural heritage is a rich and diverse legacy that shows evolution through many centuries of history. The Mediterranean landscape is the result of a long process of human activity in the physical environment, which makes the cultural landscape concept remarkable. Despite its growing interest, most cases are still exposed to different types of threats that can compromise their permanence. Given cultural variety, its consideration requires a multidisciplinary approach to provide scientific knowledge and to assess its values from different points of view (e.g., territorial, historical, technical, artistic, etc.). The valleys of Marina Alta are a most interesting example of different periods of history, from prehistory to recent rural life. Mountain conditions have favoured the survival of rural heritage, which is not that affected by the threat of better communicated areas and can be consider a place of exceptional value. In this context, our paper focuses on houses and hamlets of a Muslim origin that date back to at least the 13th century according to archival documents. Scattered in valleys, they are essential to understand historic transformations. They are directly related to the natural environment, are located in and have adapted to mountains to obtain small farming areas with small irrigated areas. Given their present state of ruin, an architectural assessment is needed to recognise the values and threats, and to make proposals for their conservation as a specific contribution to be considered part of an interdisciplinary vision.
\end{abstract}

Keywords: heritage conservation; architectural documentation; vernacular architecture; cultural landscape

\section{Research Aim}

The complexity of cultural landscapes means that they must be holistically interpreted by considering many factors. They face several threats and difficult balances have to be struck for their suitable conservation. Defining their conservation strategies is a difficult task. According to the recommendation of international charts of cultural heritage, conservation must start with research work to evaluate the values, threats, and state of preservation of heritage.

The paper aims to conduct architectural studies based on detailed research to assess the cultural landscape. A complete methodology is proposed, including an architectural survey to define geometry and characteristics to perform different analyses, e.g., construction systems, materials, consideration of phases and original typology, applied to a series of cases in a certain geographical area. The process includes evaluation results and conservation proposals. 


\section{Introduction}

\subsection{Heritage and Cultural Landscape}

The present work fits into the research lines of architectural heritage, specifically of that which, given its situation, is closely related with the territory in which it is located because it confers character, and is representative and characteristic of the place.

It is important to start with a conceptual basis, bearing in mind the principles and values described in the letters and documents that official international organisations hold in reference to the subject.

The first obligatory reference is the Convention Concerning on the Protection of World Cultural and Natural Heritage [1]. Article 1 considers cultural heritage not only to be monuments. It is remarkable that it takes into account the fact that the interest in some groups of buildings can be enhanced because of their place in the landscape from a historical point of view. It also includes the concept of sites as "... the combined works of nature and man ... which are of outstanding universal value from the historical, aesthetic, ethnological or anthropological points of view".

The European Landscape Convention [2] emphasises the quality and diversity of European landscapes as a common resource, and points out the importance of cooperating towards their protection, management and planning. UNESCO defines cultural landscape [3] as the representation of the combined works of nature and of man "They are illustrative of the evolution of human society and settlement over time, under the influence of the physical constraints and/or opportunities presented by their natural environment and of successive social, economic and cultural forces, both external and internal".

Besides, some complex values should be considered as Community Identity [4] in relation to the acknowledgment that cultural landscapes form part of the living memory of past generations and can provide connections to future generations. Other documents [5] state evocative concepts, such as "the spirit of place", which can be intangible, but tangible in buildings, sites, and landscapes.

Apart from recognising its values, there is concern about the scientific knowledge required for its conservation. It is worth highlighting the documents that incorporate important issues on the ways to move forward as part of this intention. Common interest is being shown worldwide, and documents that establish strategies exist [6]. It is commonly accepted that research is the most basic work in the conservation process, which must start with an inventory of historic sites and in-depth research into the selected ones.

Survey and Recording are essential parts of the physical research of a place that make detailed and thematic knowledge possible. Moreover, an assessment aims to determine the values of a site, its threats, and state of preservation.

In addition to the international context, the regulations and official documents in force in the study area should be considered. In State terms, the National Plan for Cultural Landscape of the Spanish Ministry of Education, Culture and Sport should be noted. This instrument is used to safeguard landscapes of cultural significance. Likewise, the Valencian Spanish Autonomous Community establishes categories of historic places and cultural parks as spaces that contain significant elements of cultural heritage, which are integrated into a relevant physical environment. It also proposes specific tools, such as a Landscape Inventory.

\subsection{Geographical and Historic Context}

The study area's geographical framework is constituted by a mountain range that spreads to the south of the Valencian Community. It is a well-known pre-Baetic domain characterised by strong limestone folds that shape a series of enclosed valleys around small fluvial watercourses. The dominant landscape responds to general Mediterranean mountain features, characterised by little irregular rainfall and rocky marked sloping lands (Figure 1).

Conditions are adverse, which makes farming hard. Much effort has been made to transform and humanise mountains. After rocks have been removed and transported, they are used to build 
terrace walls to retain soil and to obtain mountain areas to grow crops on. Human development is conditioned by the environment it is implemented into, and the land is worked by interventions that adapt to the natural scale of places.

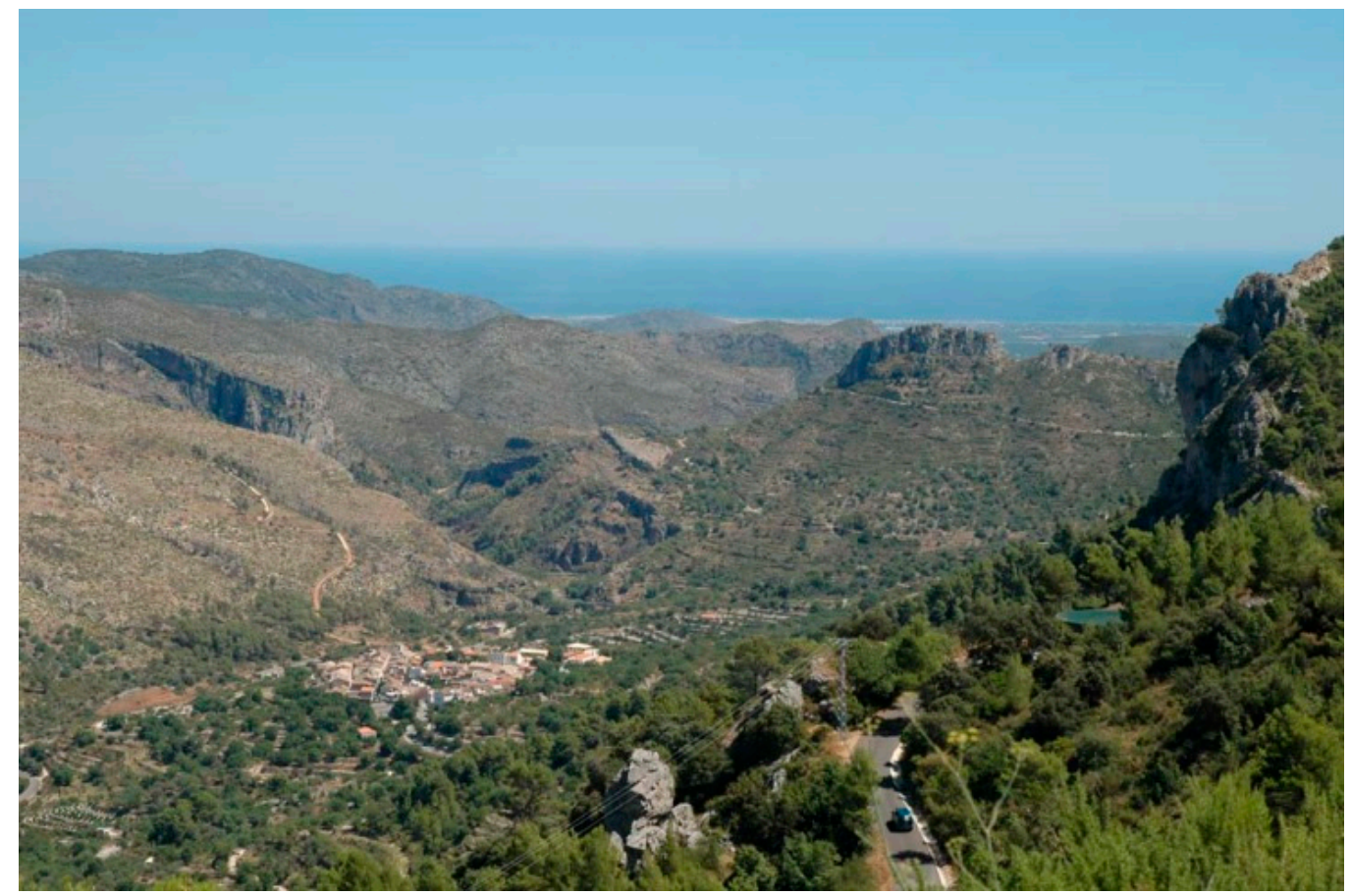

Figure 1. The natural and human landscape in Vall de Gallinera.

This area has been inhabited from time immemorial, which makes its historic stratifications remarkable, as are prehistoric rock-art sites. In fact, they are included in the UNESCO World Heritage List, in the "Rock Art of the Mediterranean Basin on the Iberian Peninsula" [7], a large group of sites that provides an exceptional picture of human life in European Prehistory through paintings in shallow open-air shelters.

During the Iberian period, occupation took place on the highest mountain tops where some settlements were found. During the Roman period, the few relics found suggest certain alienation given the mountainous nature of these valleys, which are the outskirts of the Roman city of Dianium. Barely any significant material remains have been found that date back to these periods.

The most important transformations in the territory have taken place since the Muslim conquest, with the arrival of Arab-Berber immigrants since the 8th century. New settlements appeared and spread throughout the valleys. They are associated with reduced irrigated area having adapted to mountains by constructing terraces built with stone walls for agrarian production purposes. At the same time, they responded to defence needs and impressive fortresses were strategically built and located.

After the Christian conquest halfway through the 13th century, the Muslim population persisted, be it under the control of the feudal lord. The valleys are densely populated during the Mudejar and Morisco periods, in numerous small hamlets that grouped just a few families. The Expulsion of the Moriscos in 1609 was a point of cultural rupture that led to depopulation in the territory. Later, the Christian repopulation took place, who occupied some existing houses and towns, whereas other places were permanently abandoned. Farming activity continued in the 18th and 19th centuries and areas to grow crops on among mountains were gained. Interesting rural samples related to farming and sheep-herding development appear: terraces, farmhouses, and cisterns [8].

The characteristics of the study area can be directly related with the Cultural Landscape definition, given the combination of human action and nature over time, and its exceptional value and representativeness in the history of this land. Indeed, in the categories set out by the World Heritage 
Convention [3], we find an "organically evolved landscape", characterised by the human transformations of a natural environment. It falls in the sub-categories of "continuing landscape" because it shows the evolution over time associated with the traditional way of life which retains an active social role in contemporary society. The interest and complexity of these lands have motivated studies by public institutions, which have studied elements from different historical times $[9,10]$.

\subsection{The Scattered Settlements}

The analysis of the landscape and historical context highlights the importance of the Andalusi stage in the origin of this region's characterisation. The best-known architectural evidence from this period consists of castles or fortresses that are strategically located for defence purposes. However, it is also indispensable to observe the scattered small settlements and rural houses when assessing the historical complexity of the territory.

From the wide Al-Andalus context, most rural settlements have unfortunately disappeared, and only some barely recognisable ruins or archaeological vestiges can be found. Nevertheless, the study area is a notable exception because architectural features are still recognisable. Although these places are in ruins and in danger of disappearing, they are still useful for observing the features of the hamlets of the Moriscos who inhabited these lands, which was a point of cultural separation and abandonment. Some of these places have not been re-inhabited, but have been reused as sheds for sheep. Others were repopulated by Christian settlers and have remained inhabited to become today's villages (Figure 2).

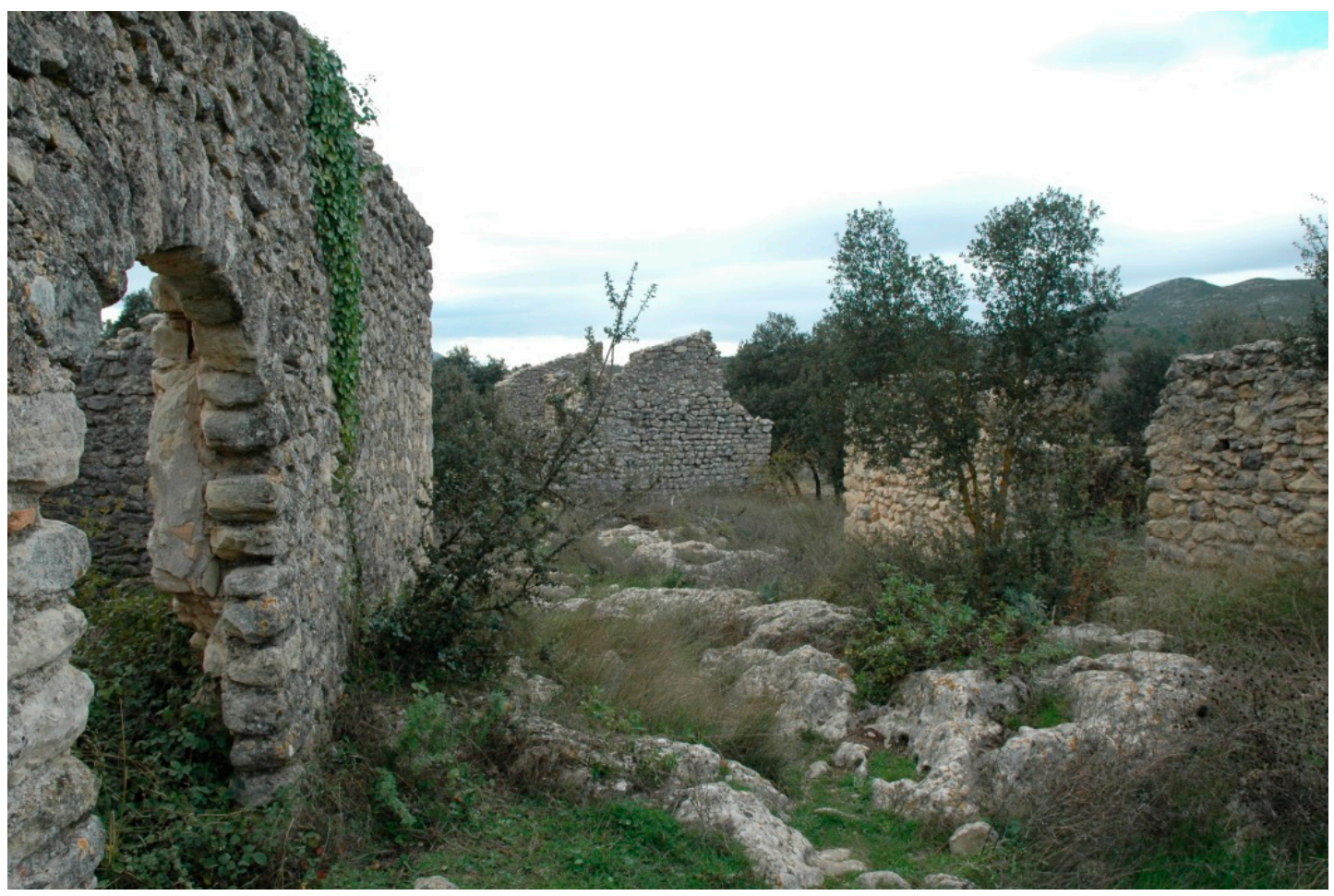

Figure 2. View of the current state of a case. Case: L'Atzuvieta, Vall d'Alcalà.

The remaining architecture is in great danger of extinction, something which would entail losing the memory of more than seven centuries of Muslim culture. Cases require a specific methodology for their research that is in line with other research works of architectural assessment of rural architecture [11] and studies for cataloging and dating of architectural heritage [12]. 


\section{Research Method}

\subsection{Definition of the Geographical Area}

To conduct this study, the geographical area was defined according to its common characteristics and values. The survey's research area comprises the valleys of Marina Alta district, set back from the coast by some $30 \mathrm{~km}$ between Alicante and Valencia. They correspond to what are today's municipal areas: Vall d'Alcalà, Castell de Castells, Vall d'Ebo, Vall de Gallinera, and Vall de Laguar, all in the province of Alicante, in the Valencian Community, Spain (Figure 3). Nowadays, this land is scarcely populated. The inhabitants in each place form several scattered and small centres. Populations increase notably at weekends and during holiday periods. Some farming activity continues and is based mainly on growing cherry, olive, almond, and carob trees.

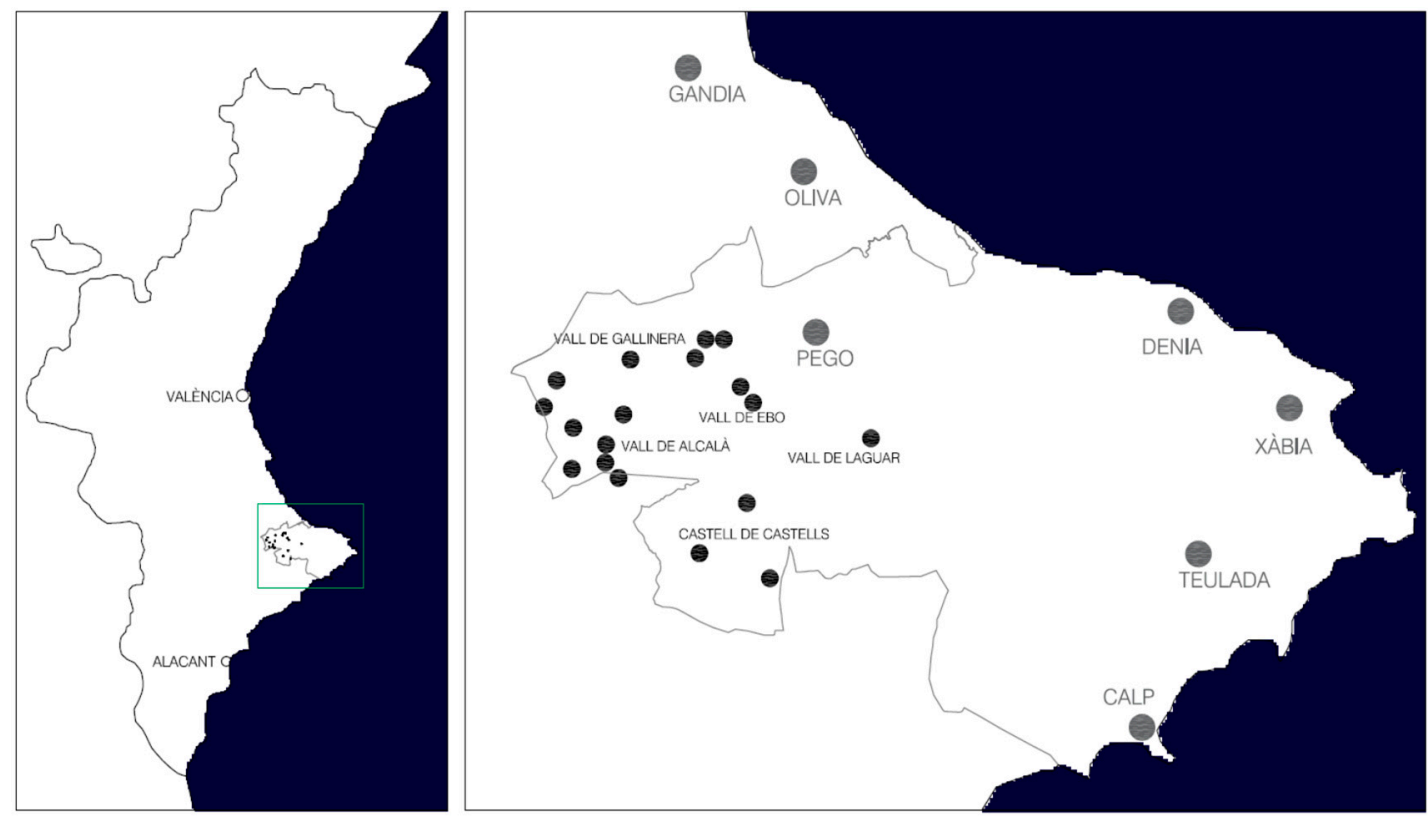

Figure 3. Location map of the survey area. Studied cases: Vall d'Alcalà: Atzuvieta, Benialí, Benixarcos, Cariola, La Roca. Castell de Castells: Aialt, Petracos, Vitla. Vall d'Ebo: Cairola, Serra. Vall de Gallinera: Alcudia, Benimarsoc, Benimoamet, Solana Benissili, Solana Carroja. Vall de Laguar: Isbert.

\subsection{Historical Study}

Interdisciplinarity is fundamental to gain cultural landscape knowledge. More specifically, architectural landscape research needs to incorporate rigorous studies conducted from the history discipline. In this case, the basis must include knowledge from historical periods in eastern regions of Al-Andalus [13]. Specifically for architecture, the interest in this matter has been pointed out in some publications [14,15]. Beyond a general vision, it is necessary to bear in mind the studies of documentary references that allow us to know the list of cases dated during the period that we defined [16].

As a whole, documentary sources confirm the existence of at least 44 places that had existed during the considered period and in the study area. Some appear in censuses from the 13th century, but had also existed beforehand, as demonstrated by the Islamic ceramic work encountered. Others are cited for the first time in censuses of the 14th century. Of them all, 15 have remained inhabited to the present day, and are constantly developing and are some of our present towns. However, this study has focused on the 29 places that are no longer inhabited, of which 16 have been architecturally identified and studied. The remaining 13 have disappeared or have not been definitely identified. Based on these data, a list of the places that existed was drawn up. This led to the next phase, that of locating them by consulting aerial photogrammetry maps and starting fieldwork and studies in situ. 


\subsection{Architectural Survey}

The conducted work falls in line with studies and research about the conservation of architectural heritage. One of its fundamental aspects is to read architecture as a document that preserves the traces of its construction history. Directly observing buildings is the basic source on which all subsequent work is done. An architectural survey is performed by recording information that completely describes the asset's physical configuration: geometry, construction systems, materials, state of conservation, etc. It follows a process accordingly with the indications of the international charts [17].

Data collection methods are defined by taking into account certain difficulties given the status of abandonment, ruin, and invasive vegetation. The survey was carried out mainly by using digital photogrammetry (Figure 4) and combining traditional techniques of specific details, along with an extensive photographic report. Each case was surveyed and digital models were made to completely define the current state. A complete set of plans was drawn, starting with the site plans of hamlets. For each building, floor plans, sections, elevations, and specific details were produced. This valuable documentation takes into account the abandonment and imminent danger of disappearance (Figure 5). It acts as a starting point to support analyses and for the understanding of heritage and its related values as an essential part of the conservation process.
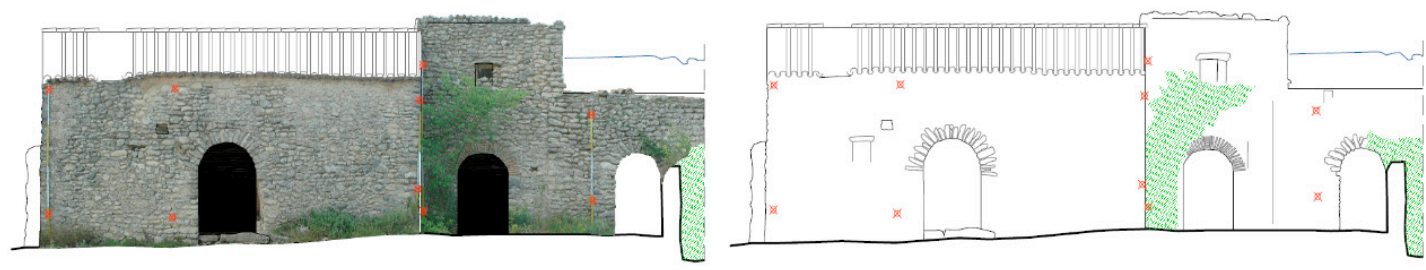

Figure 4. Example of the data collection process that has been applied to all the cases: Photogrammetry and architectural drawing.

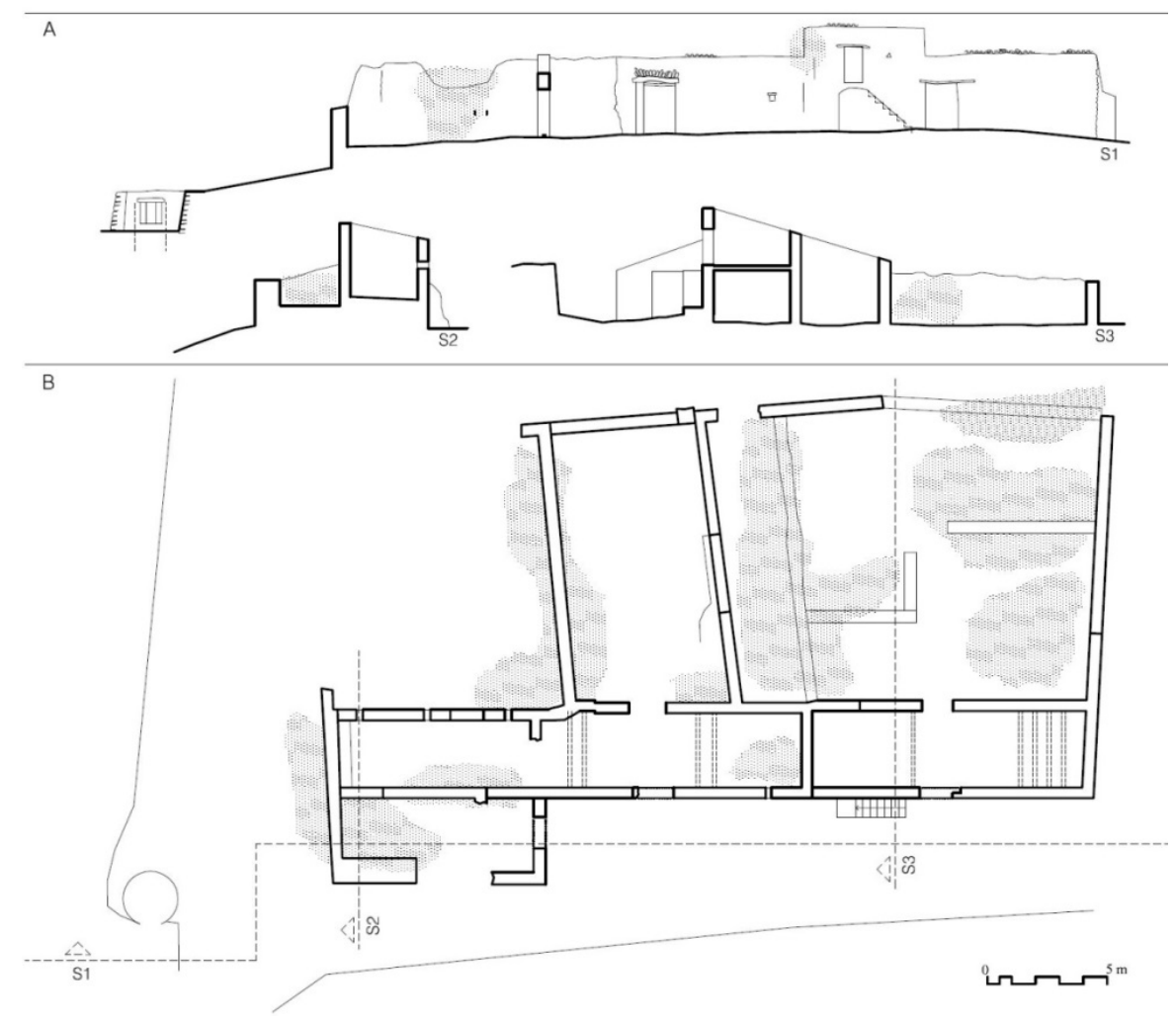

Figure 5. Architectural drawings. (A): Sections and elevations, (B): Floor plans. Case: Benialí, Vall d'Alcala. 


\subsection{Specific Studies}

The current state of the depopulated villages poses a series of problems as to finding out about the original architecture. They have been affected by overlays over several centuries, and have subsequently been abandoned and ruined. No adequate interpretation of the conserved architecture is obvious, and an in-depth analysis is necessary. Thus, specific studies are added to the general planning.

\subsubsection{Construction Systems and Building Materials}

It is possible to read the collected data to discover the ways in which materials were combined to construct dwellings. Much emphasis has been placed on defining the construction systems that shape the architecture: walls, spans, ceilings, roofs, flooring, renderings, etc. Given their ruinous state, it is necessary to establish the hypothesis for disappeared parts through detailed observations of traces of missing elements.

The construction materials of this vernacular architecture are related to their availability. Stone is the predominant material in the area, which is combined with some earth, lime, cane, and wood. In their current appearance, stone walls prevail and different fabrics are observed (Figure 6). After a thorough observation of wall surfaces, it was possible to define different kinds of stone masonry: rubble stone masonry, coursed rough stone masonry, and tapia.
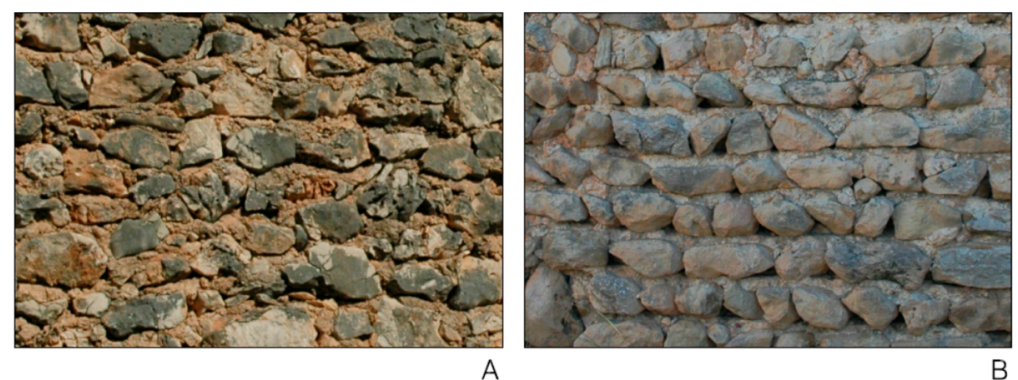

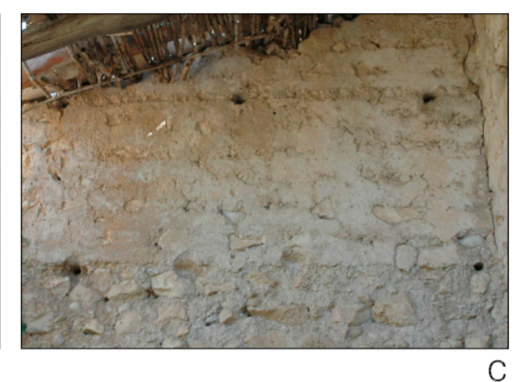

C

Figure 6. Compilation of detected wall fabrics. (A): Rubble stone masonry, (B): Coursed rough stone masonry (C): Tapia.

In the studied cases, tapia can be detected when masonry is observed laid out in horizontal courses between lime mortar, with a flat surface that maintains the trace of the wooden planks and other elements used. Although ordinary masonry is generally observed, the tapia technique should be highlighted because it is present in the original parts and oldest fabrics. As already known, the material used in the tapia process is poured into a formwork and compacted. Then, the formwork is removed and placed to continue building the wall. This technique is also known as rammed earth, but it is a special type in this area as the main material is not earth. It contains a large proportion of stone bound by mortar, that is very hard given the masterly use of lime, which makes walls very strong and durable (Figure 7). 


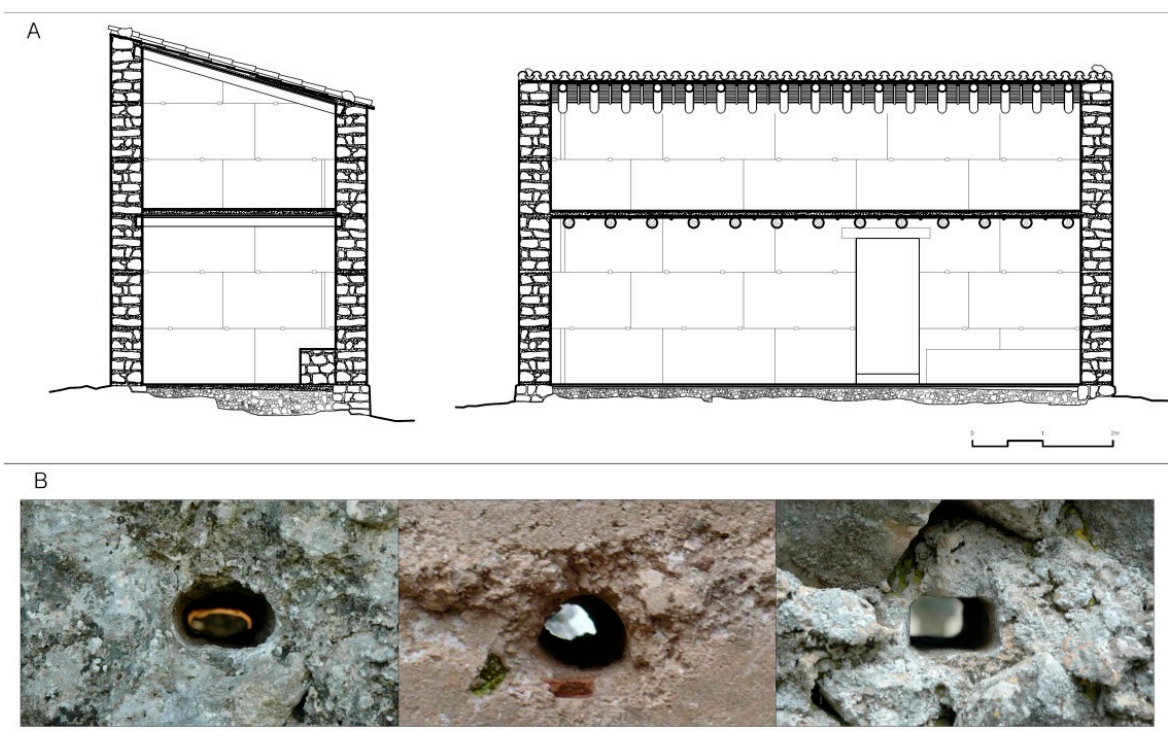

Figure 7. (A). Restitution of tapia modulation; (B): Putlog holes of horizontal timbers.

\subsubsection{Overlapping Phases}

The current state of buildings must be interpreted from a diachronic point of view. Ancient dwellings have undergone an intensive remodelling in the 18th and 19th centuries as they have been adapted to livestock pens.

A stratigraphical analysis was carried out by observing the different parts and their temporary relations. This allowed the determination of some common phases associated with different construction techniques (Figure 8). Given the vernacular character of this architecture, some constructive techniques have persisted over time. Although the contributions from all periods to buildings must be respected, the identification of different phases allows us to advance in knowledge about primitive dwellings (Figure 9).

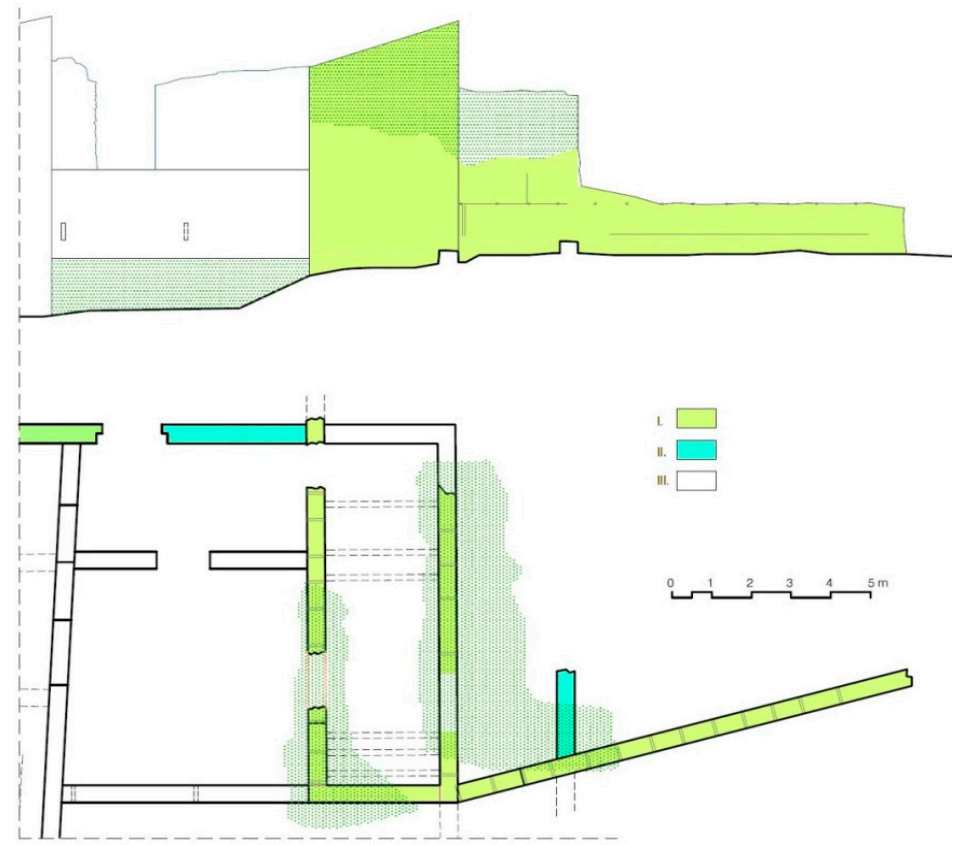

Figure 8. Construction techniques related to the temporary hypothesis. I: Tapia, II: Coursed rough stone masonry, III: Rubble stone masonry. 

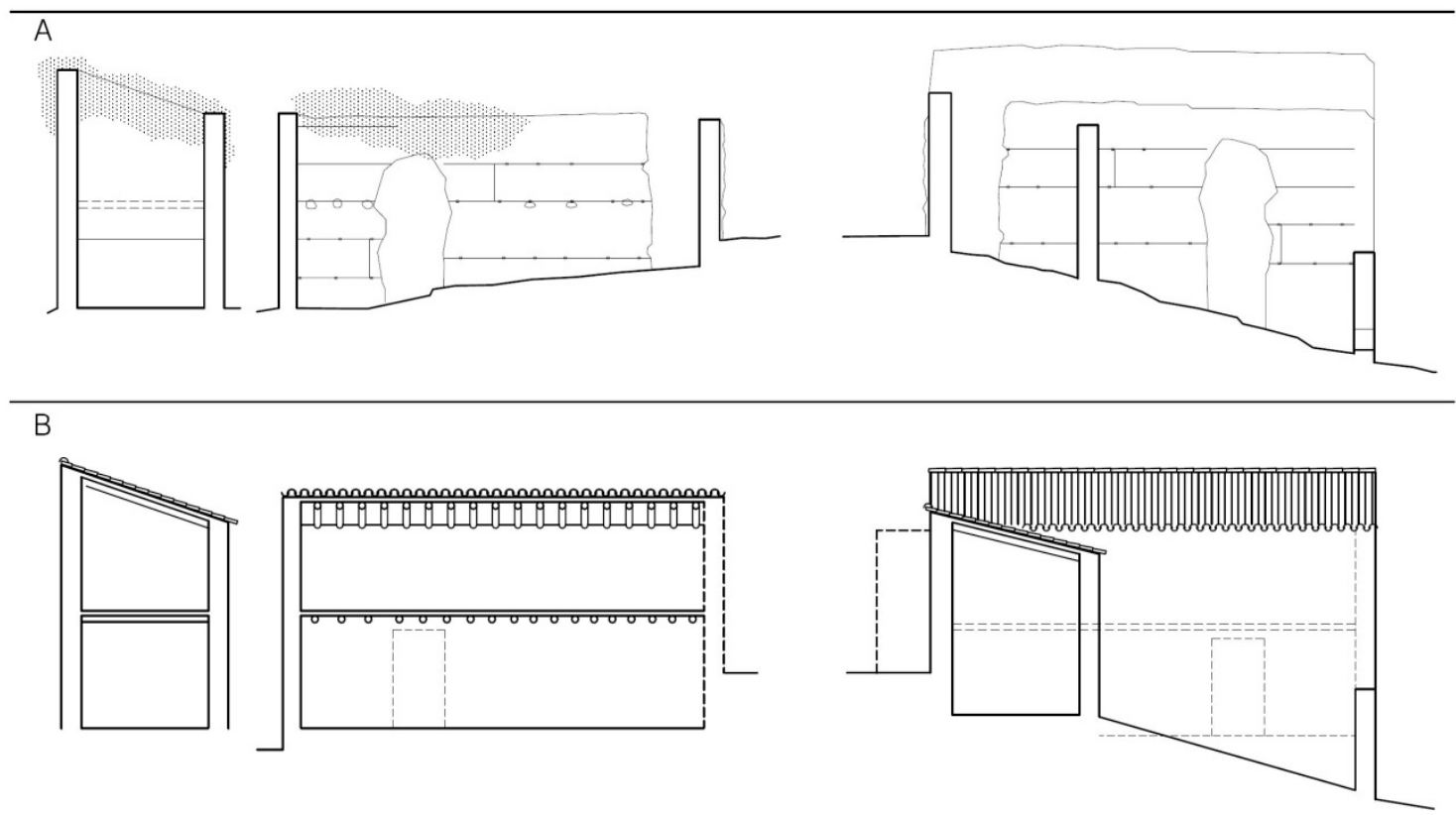

Figure 9. (A): The ruinous current state. (B): The graphic restitution of ancient architecture.

\subsection{Catalogue}

The deep analysis developed for all the cases of this architectural heritage, according to the specific research method, provides a new architectural study. The documents drawn up constitute a catalogue [18]. This is an extensive work that incorporates all the hamlets in the area, 16 places divided into different groups of houses, with an antiquity proved by the documentary sources.

This catalogue was formed in accordance with the indications to protect architectural heritage [19]. For each case, it includes all the information organised into fields: General data: name, placement, historic reference; Architectural study: survey, description, construction systems, materials, phases; Synthesis. This means it can be used as a guide for standardised studies, promotes working methodology, and makes subsequent publications easier. The documentation is objective and has its own independent value, which allows consultations and comparisons, making it possible to state the features of the original houses.

It permits not only the documentation of heritage, but also an assessment as the initial action taken towards its protection. In addition, collected data are a first step to be included in GIS systems, with the implementation of thematic maps in order to manage all the associated information and to help update the geographic inventory, as has been made in similar contexts [20].

\section{Results}

Throughout the research process, and after the detailed analysis of an extensive area, comes the time to make a joint estimation of the features and values to be preserved. The importance of this cultural landscape has to be evaluated as the area that possibly best preserves the authentic dispersed Andalusian settlements throughout the Hispanic world. Despite the ruined state of settlements in the present-day, they are a material documentation of exceptional value. This study enables the knowledge of spaces for this unique architecture, which is more than 8 centuries old. During the period studied, the architecture shows a series of invariables, such as the use of various types of construction and different technologies in a Muslim-Andalusi cultural concept that extends to the Mudejar and Morisco periods.

The contribution of architectural research, through the analysis of all the data in the catalogue, makes it possible to determine original architectural characteristics, specifically regarding wall fabrics and typology (Figure 10). 


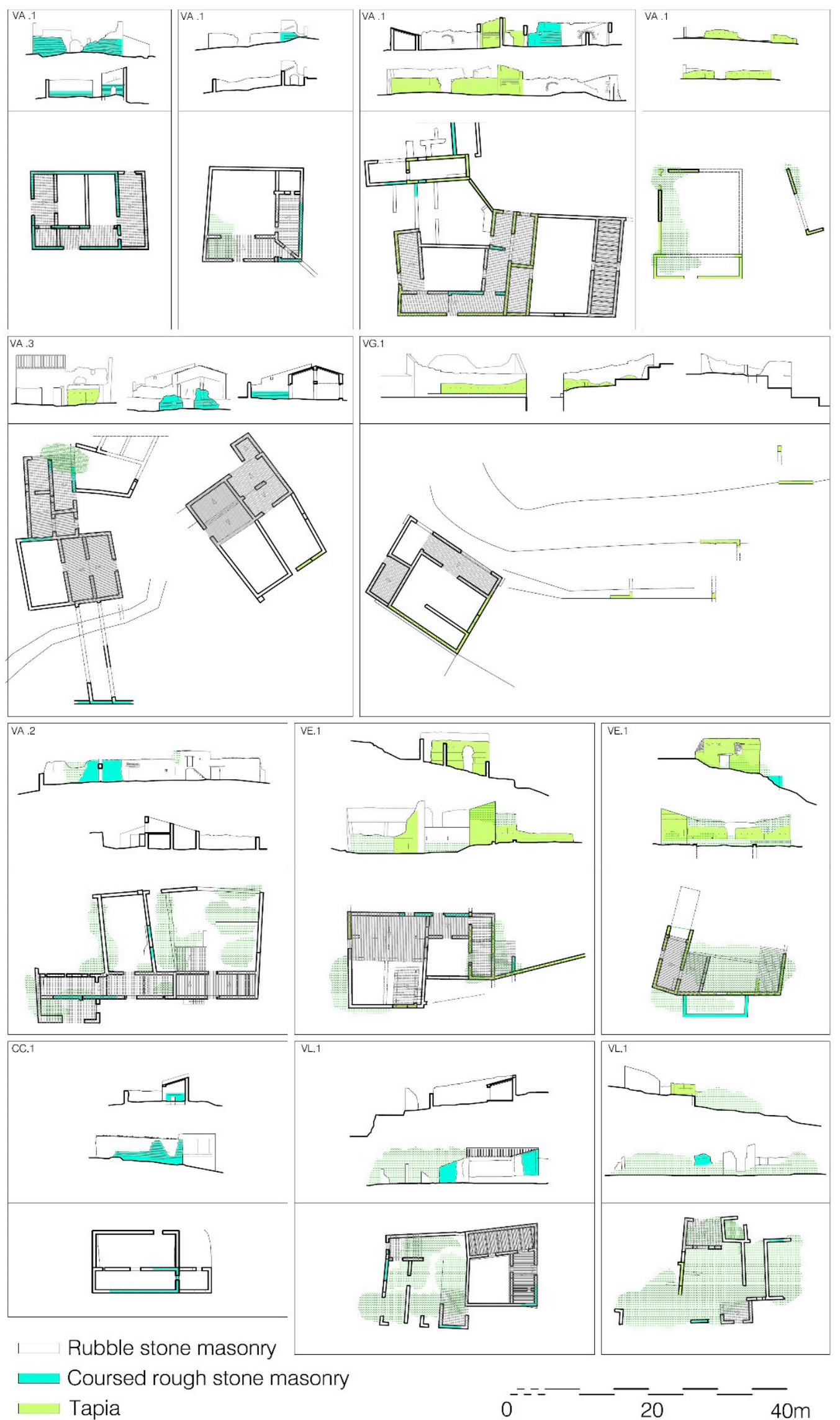

Figure 10. Sections, elevations, and floor plans with detected wall fabrics. Selected cases. Vall d'Alcalà (VA): 1 Atzuvieta (1), Benialí (2), Cariola (3). Castell de Castells (CC): Aialt (1). Vall d'Ebo (VE): Cairola (1). Vall de Gallinera (VG): Solana Benissili (1). Vall de Laguar (VL): Isbert (1). 


\subsection{Wall Fabrics}

The tapia technique should be highlighted because the study confirms that it is used only in those places that date back to before the 13th century, and it was not used later than 1609 in this area. For this reason, it is important to consider this technique because it indicates authenticity, and allows one to differentiate among the original architecture's features.

Based on the remains of walls, the forming system can be defined quite precisely. The dimensions and the way of arranging the main components are repeated, which have been detailed. The habitual dimensions of each wall section are: $165 \mathrm{~cm}$ long, $80 \mathrm{~cm}$ high, $45 \mathrm{~cm}$ thick. Dimensions of 260, 110, and $45 \mathrm{~cm}$, respectively, have been exceptionally observed in localised parts. It is an input to the knowledge of the mensiochronological studies. This form of wall is also directly related with that used in the fortresses found in the area, which are more accurately dated [21].

\subsection{Typology}

Architectural original spaces and typologies have been determined for the first time after the reading of the different phases. The basic typology of a dwelling is an elongated space between parallel loading walls. The best preserved cases attest that they were 2-storeyed houses with a sloped roof. The interior width measures between $2.55 \mathrm{~m}$ and $2.80 \mathrm{~m}$ in the original rooms. This is remarkable because widths are greater, more than $3 \mathrm{~m}$, in subsequent phases.

These units are grouped into different forms in conjunction with perimeter walls, which demarcate a large unroofed enclosure or patio. Settlements were formed by a few houses situated near to one another, but not attached. On a territorial scale, they are scattered in valleys in relation to agricultural use, which outlines a humanised landscape.

\subsection{Values}

The conducted study confirms the interest and exceptionality of the rural dwellings that date back to these centuries. This humble heritage has managed to survive and is essential for understanding the landscape of this historic time.

Given the nature of the cases, values are related to their setting and territorial scale and, by respecting the characteristics of each individual element, they must be considered with the landscape to be substantial parts of a whole. They form part of a set of elements: fortresses, irrigation systems, cultivation terraces, paths, and ways.

The characteristics of these settlements, which are spread out through the region, demonstrate the relationship between architecture and landscape. The Cultural Landscape concept fits perfectly as the combined work of nature and humankind by expressing the intimate relationship between peoples and their natural environment over time [22,23].

\subsection{Proposals}

Regarding the cases under study, despite their doubtless values, most of them do not receive suitable legal protection. Although certain steps have been taken to protect them in some cases, they are currently endangered and face threats of being transformed or eliminated. In the overall consideration, the first action proposals must address them being recognised and protected.

Given the current decayed state of this representative architectural heritage, the need to protect arises. Interventions must solve serious stability and conservation problems by respecting the original architectural design, materials, construction systems, and techniques, such as tapia, to simultaneously safeguard material remains and their value. The proposal for specific cases has been studied [24]. As the state of conservation and problems are similar in the different studied cases, general criteria have been made.

The first objective of intervention is to safeguard. Buildings must be freed of the vegetation that affects them. In a ruined state, the disappearance of roofs and floors has worryingly reduced 
the safety and stability of walls. To halt the deterioration process, consolidation and stabilisation are needed. At the same time, demolishing missing parts hinders the perception of the original configuration of spaces. Here, the aim is to avoid losing elements that can help us to understand the Architectural type.

Another objective is to respect materials and construction systems by preserving the historic value, and not alter any trace of original fabrics or any sign of overlapping periods. This is essential for reading a monument as if it were a document. The reconstruction of missing parts must be reduced to what is strictly necessary. It has to be integrated with the whole, but must remain distinguishable from the original work so that restoration does not become a falsification.

Another main objective is to facilitate public access by establishing an itinerary to guarantee the safety of visitors and to facilitate observations and ensure respect for the monument. The aim here is to recover the historical dimension of the rural settlement by remembering the houses that have disappeared, and by recreating the immediate environment. To understand the place and its relationship with other historical sites, viewpoints are proposed to direct the vision towards cultural or natural landmarks and to enjoy scenic views.

\section{Conclusions}

Cultural landscape represents the combined work of humans and nature, and is a type of very complex patrimony that needs multidisciplinary interpretation. In the considered area, the rural architecture that dates back centuries provides clues to help to interpret the territory's current configuration. Destruction, alteration, and scarce appraisal and appreciation due to ignorance endanger the site and facilitate its disappearance.

An architectural assessment methodology is proposed. Research starts with documentation and evaluation of the historical setting, allowing the location of the remaining architecture in the territory. The study is based on direct observations and analysing the conserved outward appearance of materials. A complete survey has been performed, architectural traces have been studied, and the most significant elements have been valued. This work proposes implementing inventories and catalogues to collect objective information and to facilitate diffusion and international exchange.

The study confirms the interest of the cases. This area of Mediterranean valleys retains a unique assemblage of old villages with cultural heritage value in relation to the Muslim period. These buildings have accrued meaning over time. This paper attempts to contribute to the safeguarding of these cultural heritage places for present and future generations.

Funding: This research received no external funding.

Conflicts of Interest: The authors declare no conflict of interest.

\section{References}

1. Convention Concerning the Protection of the World Cultural and Natural Heritage; The United Nations Educational, Scientific and Cultural Organization (UNESCO): Paris, France, 1972; Available online: https: / / whc.unesco. org/archive/convention-en.pdf (accessed on 20 October 2017).

2. European Landscape Convention; Council of Europe: Florence, Italy, 2000; Available online: https://rm.coe.int/ 1680080621 (accessed on 20 October 2017).

3. Operational Guidelines for the Implementation of the World Heritage Convention; The United Nations Educational, Scientific and Cultural Organization (UNESCO): Paris, France, 2017; Available online: https:/ / whc.unesco. org/en/guidelines/ (accessed on 20 October 2017).

4. The Florence Declaration on Heritage and Landscape as Human Values; ICOMOS: Florence, Italy, 2014; Available online: https://www.icomos.org/images/DOCUMENTS/Secretariat/2015/GA_2014_results/ GA2014_Symposium_FlorenceDeclaration_EN_final_20150318.pdf (accessed on 10 January 2017).

5. Declaration on the Spirit of Place; ICOMOS: Quebec, QC, Canada, 2008; Available online: https:/ / whc.unesco. org/uploads/activities/documents/activity-646-2.pdf (accessed on 10 January 2017). 
6. Principles for the Conservation of Heritage Sites in China; ICOMOS: Beijing, China, 2015; Available online: http:/ / openarchive.icomos.org/1650/ (accessed on 10 January 2017).

7. Rock Art of the Mediterranean Basin on the Iberian Peninsula. UNESCO World Heritage List. 1998. Available online: https: / / whc.unesco.org/en/list/874 (accessed on 15 February 2018).

8. Christie, N.; Beavitt, P.; Gisbert, J.A.; Seguí, J.; Gil, M.V. Ethnography and Archaeology in Upland Mediterranean Spain. Manolo's World: Peopling the Recent Past in the Serra de L'Altmirant; University of Leicester: Leicester, UK, 2004; ISBN 0953891461.

9. Muñoz, A.; Soler, R.; Soler, A. Proyecto URBACOST Corredor del Serpis; Generalitat Valenciana: Valencia, Spain, 2006; ISBN 9788448245870.

10. Grau, I.; Segura, J.M.; Soler, A.; Soler, R.; Torró, J.; Vives, M. Estudio del Paisaje Cultural y Arquitectónico Mediterráneo; Universitat Politècnica de València: Valencia, Spain, 2016; ISBN 9788490484784.

11. Vehbi, B.O.; Yuceer, H.; Hurol, Y. Rural carob warehouses in Cyprus: An assessment of architectural and structural characteristics. J. Archit. Conserv. 2016, 22, 18-47. [CrossRef]

12. Ortiz-Cordero, R.; Hidalgo Hernandez, R.E. Multivariate study and proportion study for classification and dating of Islamic Al-Andalus' minarets: A first approach. J. Cult. Herit. 2017, 24, 117-123. [CrossRef]

13. Torró, J. The eastern regions of Al-Andalus before the conquest by Catalonia-Aragon: An overview. Catalan Hist. Rev. 2012, 5, 11-27. [CrossRef]

14. Bazzana, A. Maisons d'Al-Andalus. Habitat Médiéval et Structures du Peuplement Dans l'Espagne Orientale; Casa de Velázquez: Madrid, Spain, 1992; ISBN 8486839300.

15. Torró, J.; Ivars, J. La vivienda rural mudéjar y morisca en el sur del País Valenciano. In La Casa Hispano-Musulmana. Aportaciones de la Arqueología; Bermúdez, J., Bazzana, A., Eds.; Junta de Andalucía: Granada, Spain, 1990; pp. 73-97. ISBN 8486827051.

16. Lapeyre, H. Geografía de la España Morisca; Universitat de València: Valencia, Spain, 2011; ISBN 9788492521753.

17. Carta del Rilievo Architettonico; Castell Sant Angelo: Rome, Italy, 2000.

18. Soler-Estrela, A. La Arquitectura de Los Despoblados Moriscos en Los Valles de la Marina Alta. Ph.D. Thesis, Universidad Politécnica de Valencia, Valencia, Spain, 2009.

19. Convention for the Protection of the Architectural Heritage of Europe. Council of Europe, 1985. Available online: https: / /rm.coe.int/168007a087 (accessed on 14 March 2018).

20. Vacca, G.; Fiorino, D.R.; Pili, D. A spatial Information System (SIS) for the Architectural and Cultural Heritage of Sardinia (Italy). Int. J. Geo-Inf. 2018, 7, 49. [CrossRef]

21. Soler, A.; Soler, R.; Ortega Pérez, J.R. Restoration of the stone tapia of hsin al-Qala (Castell d'Alcalà de Gallinera), Alicante, Spain. In Rammed Earth Conservation; Mileto, C., Vegas, F., Cristini, V., Eds.; Taylor \& Francis Group: London, UK, 2012; pp. 413-418. ISBN 9780415621250.

22. The ICOMOS Charter on Cultural Routes; ICOMOS: Quebec, QC, Canada, 2008; Available online: https: / / www.icomos.org/images/DOCUMENTS/Charters/culturalroutes_e.pdf (accessed on 14 March 2018).

23. Mitchell, N.; Rössler, M.; Tricaud, P.-M. World Heritage Cultural Landscapes: A Handbook for Conservation and Management; The United Nations Educational, Scientific and Cultural Organization (UNESCO): Paris, France, 2009; Available online: http://whc.unesco.org/documents/publi_wh_papers_26_en.pdf (accessed on 14 March 2018).

24. Soler, A.; Soler, R.; Paredes, E. Architecture and Landscape in Sharq al-Andalus. The conservation of an Islamic Qarya. In Earthen Architecture: Past, Present and Future; Mileto, C., Vegas, F., Cristini, V., Eds.; Taylor \& Francis Group: London, UK, 2015; pp. 351-356. ISBN 9781138027114.

(C) 2018 by the author. Licensee MDPI, Basel, Switzerland. This article is an open access article distributed under the terms and conditions of the Creative Commons Attribution (CC BY) license (http://creativecommons.org/licenses/by/4.0/). 